Tropical Journal of Pharmaceutical Research March 2020; 19 (3): 475-481

ISSN: $1596-5996$ (print); 1596-9827 (electronic)

(C) Pharmacotherapy Group, Faculty of Pharmacy, University of Benin, Benin City, 300001 Nigeria.

\title{
Genomic analysis of tyrosine hydroxylase gene sequence variations and its association with D-9- tetrahydrocannabinol dependence in addicts
}

\author{
Maryam Javed ${ }^{1 *}$, Ali Raza1, Asif Nadeem¹, Tahir Yaqub², Muhammad Danish \\ Ahmed $^{1}$ \\ ${ }^{1}$ Institute of Biochemistry and Biotechnology, ${ }^{2}$ Department of Microbiology, University of Veterinary and Animal Sciences, \\ Lahore, Pakistan \\ *For correspondence: Email: maryam.javed@uvas.edu.pk; Tel: +92-347-4462376
}

Sent for review: 29 July 2019

Revised accepted: 27 February 2020

\begin{abstract}
Purpose: To elucidate the genetic basis of drug addiction by conducting a genetic analysis of $\mathrm{TH}$ (tyrosine hydroxylase) gene and the novel polymorphisms that might help in understanding addiction and its molecular basis.

Methods: Forty-two subjects were recruited into three groups for this study. DNA was isolated from the individuals. PCR amplification of TH gene was carried out and amplicons were sequenced. Genomic characterization of TH gene provided five polymorphic loci - TH 1, TH 2, TH 3, TH 4 and TH 5 which were found among all the groups.

Results: According to Shannon's diversity index, the studied population was between 0.0762 and 0.6032 . Heterozygosity index depicted that TH 1 locus was less heterozygous (0.3288), followed by $\mathrm{TH}$ 5 (0.3152). TH 1 (0.1462) was the least heterozygous. Genotypic analysis predicted that among these five loci, TH 4 ( $p=0.039898)$ and TH $2(p=0.851716)$ were non-significant $(p>0.05)$ and obeyed Hardy Weinberg Equilibrium (HWE) law. There are few genetic changes in the studied population that can statistically be associated with drug addiction. Still, their genotypic distribution in the gene pool was very low.

Conclusion: On the basis of these findings, drug addiction in the studied population is more likely a social issue rather than a genetic one.
\end{abstract}

Keyword: Tyrosine hydroxylase, SNP, Drug dependence

\begin{abstract}
This is an Open Access article that uses a fund-ing model which does not charge readers or their institutions for access and distributed under the terms of the Creative Commons Attribution License (http://creativecommons.org/licenses/by/4.0) and the Budapest Open Access Initiative (http://www.budapestopenaccessinitiative.org/read), which permit unrestricted use, distribution, and
\end{abstract} reproduction in any medium, provided the original work is properly credited.

Tropical Journal of Pharmaceutical Research is indexed by Science Citation Index (SciSearch), Scopus, International Pharmaceutical Abstract, Chemical Abstracts, Embase, Index Copernicus, EBSCO, African Index Medicus, JournalSeek, Journal Citation Reports/Science Edition, Directory of Open Access Journals (DOAJ), African Journal Online, Bioline International, Open-J-Gate and Pharmacy Abstracts

\section{INTRODUCTION}

Phytocannabinoids are unique products of Cannabis sativa [1]. This plant produces about 400 substances containing 60 chemicals that are famous for their unique effects [2]. The most psychoactive ingredient is D-9- tetrahydrocannabinol (THC), which is the main component of cannabinoid drug groups, and the addictive strength of cannabis also depends on the amount of THC contained in it [3].

All cannabinoids have mind-altering effects, but THC affects almost every organ system [4]. It 
increases metabolism, lowers blood pressure, but also increases bleeding [5]. Other physical alterations include increased appetite, red eyes with dilated pupils, dry mouth, shallow breathing, dizziness and slower response times [6]. Chronic effects range from minor cough to lung cancer. Major attention is given to its role in the neurotransmitter 3. 4-dihydroxyphenethylamine is also known as dopamine and its metabolic pathway is mainly through the central nervous system [7]. It plays several roles in the nervous system and in all body functions, but performs the most important function in Reward-Motivated Behavior [8]. A strong relationship between increased dopamine levels and both artificially and naturally induced pleasurable experiences by drug and reward action has been established [9]. While there are multiple recreational drugs that can elevate dopamine levels directly or indirectly, such as cocaine, methamphetamine, heroin and nicotine [10], antiseptic drugs on the other hand, are found to reduce dopamine levels [11]. Tyrosine Hydroxylase $(\mathrm{TH})$ plays a key role in the biosynthesis of dopamine [12]. The candidate $T H$ gene for this enzyme is located in the telomeric region of the " $p$ " arm of chromosome 11 at $11 \mathrm{p} 15.5$ [13]. Human $\mathrm{TH}$ gene ranges from $8 \mathrm{~kb}$ of genome, and consists of 13 exons with an exon added to enable alternative splicing and the generation of four altered mRNA molecules [14].

The present study was aimed at exploring the $\mathrm{TH}$ gene in association with THC dependence, as variations in the $\mathrm{TH}$ gene is of particular interest in understanding genetic risks of drug dependence, because of its seminal role in dopamine synthesis. The protein encoded by this gene is involved in the conversion of tyrosine to dopamine. It is the rate limiting enzyme in the biosynthesis of catecholamines. Hence, it plays a key role in the physiology of adrenergic neurons. Polymorphisms in the $\mathrm{TH}$ gene have been found to be associated with addictive behavior. Genetic analysis of the polymorphism in the $T H$ gene can be a useful tool to predict the possible susceptibility of an individual to drug addiction.

\section{EXPERIMENTAL}

\section{Sampling strategy}

To understand the correlation between tyrosine hydroxylase $T H$ gene sequence variations and drug addiction, individuals with suspected addictive behavior were recruited after taking their informed consents on pre-designed forms and briefing them about the objectives of the study. For this study, a total of 42 individuals aged 18 years or more were selected. Their urine samples were analyzed through "Multiline Drug
Testing Kit" to confirm the prevalence of Delta-9Tetrahydrocannabinol THC. "Nicotine Testing Kit" was also used for confirmation of nicotine in the urine. The 42 individuals were selected depending on the type of substance of abuse found in their urine samples. These individuals were classified into three groups. First group consisted of Cannabis smokers as test group ( $\mathrm{n}$ $=19$ ), the second group comprised of simple cigarette smokers as control for nicotine $(n=12)$, and the third group contained non-smoker subjects $(n=11)$.

\section{Blood sampling and DNA extraction}

After obtaining consent from all the individuals involved in the study, $3 \mu \mathrm{L}$ blood was collected from each individual, taking into account all the necessary precautionary measures. Blood was processed for the extraction of genomic DNA through organic method using PhenolChloroform-Isoamyl alcohol. The quality of the extracted DNA was evaluated with $8 \%$ agarose gel electrophoresis.

\section{DNA amplification and sequencing}

For PCR amplification, Primers were designed against two regions of the $T H$ gene (Table 1). Total volume of the reaction was $25 \mu \mathrm{L}$ with Taq Buffer $2.0 \mu \mathrm{L}(10 \mathrm{X})$, dNTPs $2.0 \mu \mathrm{L}(25 \mathrm{mM} / \mu \mathrm{L})$, $\mathrm{MgCl}_{2} 2.0 \mu \mathrm{L}(2 \mathrm{mM} / \mu \mathrm{L})$, Forward Primer $0.6 \mu \mathrm{L}$ (10 pM/ $\mu \mathrm{L})$, Reverse Primer $0.6 \mu \mathrm{L}(10 \mathrm{pM} / \mu \mathrm{L})$, Taq Polymerase $0.15 \mu \mathrm{L}$ (5 Unit/ $\mu \mathrm{L})$ and DNA Template $1 \mu \mathrm{L}(30 \mathrm{ng} / \mu \mathrm{L})$. Through gradient $\mathrm{PCR}$, both the primers were optimized at $56{ }^{\circ} \mathrm{C}$ and $59{ }^{\circ} \mathrm{C}$ respectively. Amplified products were analyzed with $1.2 \%$ agarose gel followed by Sanger Sequencing on gene Analyzer.

\section{Statistical and bioinformatics analysis}

All retrieved sequences were analyzed using bioinformatics and statistical tools. Polymorphic sites were identified with BLAST (https://blast.ncbi.nlm.nih.gov/Blast.cgi) and ClustalW (https://www.genome.jp/toolsbin/clustalw) software. Allelic and genotypic frequency of each locus was calculated and Hardy Weinberg testing was applied by calculating $\mathrm{Chi}^{2}$ using POPGENE32 software. Haplotypic analysis was performed with SHEsis (analysis.bio-x.cn). Association analysis was performed using One Way ANOVA.

\section{Ethical statement}

All procedures in this study were carried out in accordance with the Declaration of CIOMS [15]. Informed consent was obtained from all the 
patients and participants. All the protocols and procedures were approved by the Ethical Research Committee affiliated with University of Veterinary and Animal Sciences, Lahore, Pakistan (approval no. 082/IRC/BMR).

\section{RESULTS}

The aim of this experiment was to identify the single nucleotide polymorphism (SNP) of the Tyrosine Hydroxylase (TH) gene responsible for the biosynthesis of dopamine.

SNPs were identified by comparing the sequences obtained. A total of five variations were identified (Table 2). Sequence alignment of case and control provided the polymorphic sites (Fig 1). At locus $\mathrm{TH} 1$, an insertion mutation was detected as g.5718_5719insA. This variation was found only in control groups, hence it revealed a protective role against cannabis dependence. Contrary to this variation, $5721 \mathrm{C}>\mathrm{G}$ was present at locus TH 2 only in test samples. At TH 3 locus, a transition mutation was found, but this variation was found only in control group 1. It depicted the 5747 T $>$ C mutation as not having any association with cannabis dependence. But while considering the addictive nature of nicotine, an association was found, and that with replacement of $\mathrm{T}$ allele with $\mathrm{C}$, an individual could become susceptible to nicotine dependence. In intron-4 of the TH gene, TH 4 locus displayed $7169 \mathrm{C}>\mathrm{G}$ mutation. One more intronic variation was found as $\mathrm{TH} 5$ with 7177T>G genotype. Being intronic in location, no structural consequences were found due to $\mathrm{TH} 5$. Pictorial location of these variations can be seen in Fig 2.

Population Genetics Analysis 32 (PopGen) was used to determine the probability of the targeted mutant locus being considered as a marker. For the PopGen analysis, genotypic data was designed by assigning letter $A$ to wild type alleles, and letter $\mathrm{B}$ to mutant alleles. $\mathrm{Chi}^{2}$ testing was performed to evaluate the Hardy Weinberg Equilibrium of all the mutant loci (Table 3). To know about the relative frequency of both wild and mutant alleles on all loci, allelic frequency was calculated and both alleles were assigned with respective values out of 1 as shown in Table 3. For all loci, heterozygosity index was calculated in order to determine the probability of both alleles to exist at a particular locus. Locus TH 1 showed maximum heterozygosity values, followed by $T H 3$ locus, TH 5, TH 2 and TH 3 respectively (Table 5). According to these values, majority of the population was found to be homozygous for all loci.

Haplotypic analysis was performed using SHEsis, to analyze the linkage among the alleles at different loci, and how they associate simultaneously with the respective traits. The first combination which had Fisher's value (0.022342), Pearson's value (0.22322) and Odd Ratio 2.17 with $95 \%$ confidence interval was found to be linked with the trait (Table 6). Through One-Way ANOVA, the genetic distribution of all the alleles was determined at five loci. P-values were also recorded and 0.05 was taken as a threshold limit for significance of particular loci to be associated with addiction. According to table 6 , only mutations at locus $T H$ 2 and $T H 5$ were found to be significantly associated with addiction to Cannabis.

Table 1

\begin{tabular}{llc}
\hline Primer & Primer Sequence & $\mathbf{T}_{\mathbf{m}}$ \\
\hline Pri-1 for & 3'TTCAAAGGGTATCTGGGCT & $\mathbf{5 6}^{\circ} \mathbf{C}$ \\
intron-1 & CTG5' & \\
& 3'GGGCTGAAAAGCTCCCGAT & \\
& TA5' & \\
Pri-2 for & 3'AAAAACGTGCTCTCATCCC & $\mathbf{5 9}{ }^{\circ} \mathbf{C}$ \\
Exon-3 & CT5 & \\
& 3'TCAGGAACTCAGCCCACA & \\
& C5' \\
\hline
\end{tabular}

Table 2: SNPs Summary

\begin{tabular}{ccccccc}
\hline ID & Position & Location & Wild & Mutant & P-value & HWE \\
\hline TH1 & g.5718 5719 ins & Intron1 & - & A & 1.000000 & Non-Significant \\
TH2 & $5721 \mathrm{C}>\mathrm{G}$ & Intron1 & $\mathrm{C}$ & $\mathrm{G}$ & 0.851716 & Non-Significant \\
TH3 & $5747 \mathrm{~T}>\mathrm{C}$ & Intron1 & T & $\mathrm{C}$ & 0.003218 & Significant \\
TH4 & $7169 \mathrm{C}>\mathrm{G}$ & Intron4 & $\mathrm{C}$ & $\mathrm{G}$ & 0.039898 & Significant \\
TH5 & $7177 \mathrm{~T}>\mathrm{G}$ & Intron4 & T & $\mathrm{G}$ & 0.000004 & Significant \\
\hline
\end{tabular}

Table 3: Overall allele frequency

\begin{tabular}{lccccc}
\hline AllelelLocus & TH1 & TH2 & TH3 & TH4 & TH5 \\
\hline Allele A & 0.7083 & 0.8472 & 0.7639 & 0.8194 & 0.7222 \\
Allele B & 0.2917 & 0.1528 & 0.2361 & 0.1806 & 0.2778 \\
\hline
\end{tabular}


Table 4: Summary of heterozygosity statistics for all loci

\begin{tabular}{lcccccc}
\hline Locus & Obs_Hom & Obs_Het & Exp_Hom & Exp_Het & Nei & Ave_Het \\
\hline TH1 & 0.9722 & 0.0278 & 0.5810 & 0.4190 & 0.4132 & 0.3288 \\
TH2 & 0.7500 & 0.2500 & 0.7375 & 0.2625 & 0.2589 & 0.1641 \\
TH3 & 0.7500 & 0.2500 & 0.6342 & 0.3658 & 0.3607 & 0.3152 \\
TH4 & 0.8611 & 0.1389 & 0.6999 & 0.3001 & 0.2959 & 0.1462 \\
TH5 & 1.0000 & 0.0000 & 0.5931 & 0.4069 & 0.4012 & 0.1667 \\
\hline Mean & 0.8667 & 0.1333 & 0.6491 & 0.3509 & 0.3460 & 0.2242 \\
Std dev & 0.1185 & 0.1185 & 0.0678 & 0.0678 & 0.0669 & 0.0897 \\
\hline
\end{tabular}

Table 5: Haplotype analysis

\begin{tabular}{|c|c|c|c|c|c|c|}
\hline Haplotypes & $\begin{array}{l}\text { Case } \\
\text { (freq) }\end{array}$ & $\begin{array}{c}\text { Control } \\
\text { (freq) }\end{array}$ & Chi2 & $\begin{array}{c}\text { Fisher's } \\
\text { p }\end{array}$ & Pearson's $p$ & Odds ratio $[95 \% \mathrm{Cl}]$ \\
\hline AAAA $A^{*}$ & $41.44(0.576)$ & $11.00(0.344)$ & 5.222 & 0.022342 & 0.022322 & $2.716[1.138 \sim 6.482]$ \\
\hline$A A A A B *$ & $6.56(0.091)$ & $1.00(0.031)$ & 1.230 & 0.267504 & 0.267432 & 3.179 [0.371 27.220] \\
\hline$A A B A A^{*}$ & $0.00(0.000)$ & $15.00(0.469)$ & 38.742 & 5.239010 & 4.997010 & - \\
\hline$A A B A B^{*}$ & $0.00(0.000)$ & $4.00(0.125)$ & 9.180 & 0.002460 & 0.002457 & - \\
\hline A A B B B* & $0.00(0.000)$ & $1.00(0.031)$ & 2.226 & 0.135786 & 0.135712 & - \\
\hline$A A A B A^{*}$ & $3.56(0.050)$ & $0.00(0.000)$ & 1.674 & 0.195731 & 0.195651 & - \\
\hline B B A A A* & $7.00(0.097)$ & $0.00(0.000)$ & 3.405 & 0.065073 & 0.065024 & - \\
\hline$B$ B A A B* & $5.00(0.069)$ & $0.00(0.000)$ & 2.384 & 0.122678 & 0.122607 & - \\
\hline$B$ B A B $A^{*}$ & $4.00(0.056)$ & $0.00(0.000)$ & 1.890 & 0.169300 & 0.169221 & - \\
\hline $\mathrm{B} \mathrm{B} \mathrm{A} \mathrm{B} \mathrm{B}^{*}$ & $3.00(0.042)$ & $0.00(0.000)$ & 1.401 & 0.236537 & 0.236461 & - \\
\hline \multicolumn{7}{|c|}{$\begin{array}{l}\text { (All those frequency }<0.03 \text { will be ignored in analysis.) } \\
\text { Loci chosen for hap-analysis: } \mathrm{TH} 1, \mathrm{TH} 2, \mathrm{TH} 3, \mathrm{TH} 4, \mathrm{TH} 5\end{array}$} \\
\hline
\end{tabular}

Table 6: Association analysis of TH gene polymorphisms (mean \pm SE) on the basis of genotypic distribution

\begin{tabular}{lcccc}
\hline Locus/Genotype & AA & AB & BB & $\boldsymbol{P}$-value \\
\hline TH1 & $0.33 \pm 5.333$ & $0.33 \pm 0.3333$ & $3.33 \pm 1.6667$ & 0.284754 \\
TH2 & $8.66 \pm 1.2019$ & $3 \pm 2.5166$ & $0.33 \pm 0.333$ & 0.027911 \\
TH3 & $7.66 \pm 2.9059$ & $3 \pm 1.1547$ & $1.33 \pm 1.333$ & 0.138382 \\
TH4 & $4 \pm 1.5275$ & $0.66 \pm 0.6667$ & $7.33 \pm 1.453$ & 0.028512 \\
TH5 & $3.66 \pm 1.145$ & $0.66 \pm 0.4216$ & $4 \pm 1.9149$ & 0.175298 \\
\hline
\end{tabular}

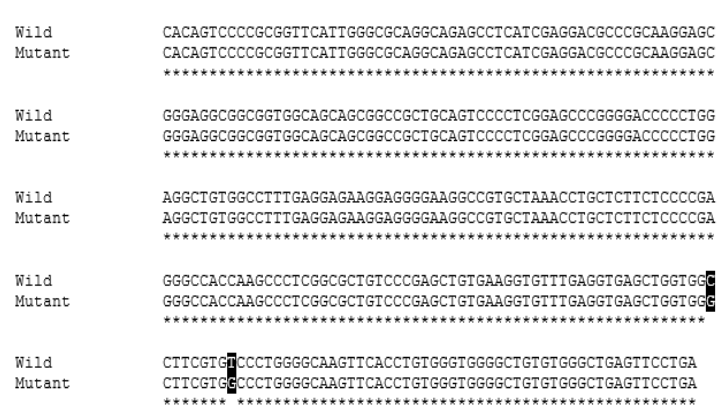

(a)

Wild TTCAAGGGTATCTGGGCTCTGGGGTGATTCCCATTGGCCTGTTCCTCCCTTAITTCCCT Mutant TTCAAGGGIATCTGGGCTCTGGGGIGATTCCCAITGGCCTGITCCTCCCTTATTTCCCT

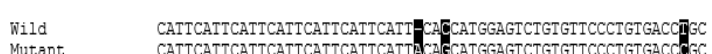

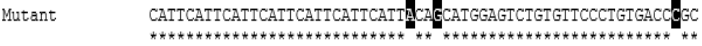

Wild ACTCGGAAGCCCTGTGTACAGGGGACTGTGTGGGCCAGGCTGGAAAATCGGGAGCTITTC Mutant ACTCGGAAGCCCTGTGTACAGGGGACTGTGTGGGCCAGGCTGGATAATCGGGAGCTTTTC

$\begin{array}{ll}\text { Wild } & A G C C \\ \text { Mutant } & A G C C\end{array}$

(b)

Figure 1: Multiple Sequence Alignment among Mutant and Wild Type for (a) Exon-3, (b) Intron-1

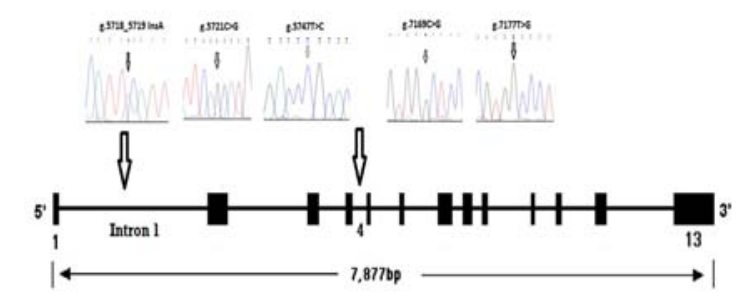

Figure 2: Chromatogram analysis of $\mathrm{TH}$ gene sequences representing mutant loci and their position

\section{DISCUSSION}

Neurotransmitters, which are important components of the nervous system, play a vital role in major behavioral traits. Dopamine being the most important neurotransmitter along with serotonin and few others, mainly control our Reward System or Reward Motivation Behavior [16]. Variable concentration of dopamine has been reported as a causative factor in major behavioral disorders like anxiety [17], depression and aggression[6]. Cannabis is the most commonly abused drug in majority of countries in the world because they are cheap and easily 
available. It contains highly psychoactive substances that can stimulate dopamine production in our body, inducing sensational feeling for a particular time [18]. Among these psychoactive chemicals, the most active substance is D 9-Tetrahydrocannabinol or THC [19]. Drug dependence is directly linked to THC dependence in Cannabis abusers [20]. THC ligation in the human brain region is linked to the dopamine system, and studies have reported that THC acts on this system and manipulates dopamine production, causing the person to feel relaxed after $\mathrm{THC}$ intake.

We hypothesized that there are certain variations in individuals' genome that affect dopamine production, and these variations make such individual susceptible to drug dependence. In dopamine biosynthesis mechanism, multiple factors are involved and major attention is given to the tyrosine hydroxylase enzyme being the rate determining enzyme of this system.

The present study was designed to investigate the role of Tyrosine Hydroxylase $(T H)$ gene as a susceptibility factor for drug addiction, which is one of the major causes of self-harm, domestic violence, child abuse, suicide, theft and burglaries and most importantly, one of the main factors causing the spread of lethal diseases such as HIV, HCV, etc. Before collecting samples, urine samples of the individuals involved in this research were analyzed for THC and nicotine presence through "Multi Line Drug Testing Kit" and "Nicotine Screening Kit" respectively. After screening, blood samples were processed further for DNA extraction. Two regions were selected for genetic analysis. First region was hyper variable tetra repeat genetic marker TH 01 in intron 1 of $\mathrm{TH}$ gene and second was exon 3 of $\mathrm{TH}$ gene. PCR amplification, followed by Sanger Sequencing and bioinformatics analysis were applied on the sequence data. A total of five variations were recorded in this study and their associations were analyzed through statistical analysis.

Similar studies were performed on individuals of Swedish, Tunisian, Polish and French origin, to find association of dopamine production in schizophrenic patients. Our results were consistent with Meloni and co-workers [21] for the Polish, and with Jonsson and co-workers [22] for the Swedish population. Allelic Frequency calculations confirmed that wild type alleles are dominant over mutant alleles in our population. According to Shannon's diversity index, the population of the study lies between 0.0762 and 0.6032 , which indicates that the population have a variety of recombinants for following loci.
Heterozygosity index was calculated for five loci. $\mathrm{TH} 1$ locus was found to possess the maximum heterozygosity (0.3288), followed by $\mathrm{TH} 5$ locus (0.3152). TH 1 (0.1462) was found to be the least heterozygous. Similarly, Haplotypic analysis was performed to investigate the probability of different polymorphisms co-existing at individual levels. Out of five haplotypes, only one was significant according to Fisher's (0.022342) and Pearson's (0.022322), having odd ratio 2.716 [1.138 6.482].

Genotypic studies predicted that among these five loci, TH 4 and $T H 2$ are non-significant $(P$ value more than 0.05$)$ for change in the gene pool. While TH 1 and TH 3, TH 5 are significantly variable ( $P$ value more than 0.05$)$. Limitations of this research include, low sample size. This baseline study provides room to explore the variation in mRNA and protein expression level, because $T H$ gene produces 4 types of transcript variants through alternative splicing of exon 1[14]. One such study was conducted by Haycock [23], in which he explored multiple protein isoforms in humans and compared them with rats. The socio-economic status of the subjects were not considered while sampling, and due to the social setup of certain societies, no female sample was included. Moreover, studies have reported that there are few other genes like DRD 1 [24], DRD 2 [25, 26], DRD 3 [27], DRD 4, DRD 5, DAT 1 [25], DBH [28] and $C O M T$, which have regulatory effects on dopamine production through $\mathrm{TH}$ expression control [29]. There is a gap for advanced neurobiological techniques to fill, which is by examining the dopamine levels in selected individuals before and after drug exposure, while putting into consideration, their genetic makeup.

\section{CONCLUSION}

There are a few genetic changes in the studied population that can be associated with drug addiction statistically, but the prevalence in our gene pool is very low. Thus, on the basis of these findings, drug addiction in the Pakistani population is more likely a social issue than a genetic one. Therefore, by reducing the social risk factor, we can combat the issue of drug addiction.

\section{DECLARATIONS}

\section{Conflict of interest}

No conflict of interest is associated with this work. 


\section{Contribution of authors}

We declare that this work was done by the authors named in this article, and all liabilities pertaining to claims relating to the content of this article will be borne by the authors. Ali Raza conducted the sampling and main wet lab experimentations, Maryam Javed designed the study plan and supervised its experimentation, Asif Nadeem conducted bioinformatics analysis of the results, Tahir Yaqub helped in preparing the manuscript, and Muhammad Danish Ahmed helped in sample collection and manuscript preparation.

\section{Open Access}

This is an Open Access article that uses a funding model which does not charge readers or their institutions for access and distributed under the terms of the Creative Commons Attribution License (http://creativecommons.org/licenses/by/ 4.0) and the Budapest Open Access Initiative (http://www.budapestopenaccessinitiative.org/rea d), which permit unrestricted use, distribution, and reproduction in any medium, provided the original work is properly credited.

\section{REFERENCES}

1. Guy GW, Whittle BA, Robson P. 2004. The Medicinal Uses of Cannabis and Cannabinoids, Pharmaceutical Press; $p 74$.

2. Aizpurua-Olaizola O, Soydaner U, Ozturk E, Schibano D, Simsir Y, Navarro P, Etxebarria N, A. U. Evolution of the Cannabinoid and Terpene Content during the Growth of Cannabis sativa Plants from Different Chemotypes. J Nat Prod. 2016; 79: 324-331.

3. Haney M, Gunderson EW, Rabkin J, Hart CL, Vosburg SK, Comer SD, Foltin RW. Dronabinol and marijuana in HIV-positive marijuana smokers. Caloric intake, mood, and sleep. J Acquir Immune Defic Syndr. 2007; 45: 545-554.

4. Acquas E, Pisanu A, Marrocu P, Goldberg SR, Di Chiara G. Delta9-tetrahydrocannabinol enhances cortical hippocampal acetylcholine release in vivo: a microdialysis study. Eur J Pharmacol. 2001; 419.

5. Eisenhofer G, Kopin IJ, DS G. Catecholamine metabolism: a contemporary view with implications for physiology and medicine. Pharmacological Reviews. 2004; 56: 331-349.

6. Volkow ND, et al. Evaluating dopamine reward pathway in ADHD: clinical implications. JAMA. 2009; 302: 10841091.

7. Bjorklund A, Dunnett SB. Dopamine neuron systems in the brain: an update. Trends Neurosci. 2007; 30: 194202.
8. Di Chiara G, Bassareo V. Reward system and addiction: what dopamine does and doesn't do. Curr Opin Pharmacol. 2007; 7: 69-76.

9. Hoffmann GF, Assmann B, Bra"utigam C, Dionisi-Vici C, Ha"ussler M, De Klerk JBC, Naumann M, SteenbergenSpanjers GCH, Strassburg HM, Wevers RA. Tyrosine Hydroxylase Deficiency Causes Progressive Encephalopathy and Dopa-Nonresponsive Dystonia. Ann Neurol. 2003; 54: S56-S65.

10. Arseneault L, Cannon M, Poulton R, Murray R, Caspi A, Moffitt TE. Cannabis use in adolescence risk for adult psychosis longitudinal prospective study. BMJ. 2002; 325: 1212-1213.

11. Musacchio JM. 2013. Enzymes involved in the biosynthesis and degradation of catecholamines. Biochemistry of Biogenic Amines, Springer, $p$ 1-35.

12. Barron AB, Sovik E, Cornish JL. The Roles of Dopamine and Related Compounds in Reward-Seeking Behavior across Animal Phyla. Front Behav Neurosci. 2010; 4: 163.

13. Craig SP, Buckle VJ, Lamouroux A, Mallet J, Craig I. Localization of the human tyrosine hydroxylase gene to 11p15: Gene duplication and evolution of metabolic pathways. Cytogenet. Cell Genet. 1986; 2: 29-32.

14. Kobayashi K, Kaneda N, Ichinose $H$, Kishi F, Nakazawa A, Kurosawa $Y$, Fujita $K$, Nagatsu $T$. Structure of the human tyrosine hydroxylase gene: alternative splicing from a single gene accounts for generation of four mRNA types. J. Biochem. 1988; 103: 907-912.

15. International Ethical Guidelines for Biomedical Research Involving Human Subjects Prepared by the Council for International Organizations of Medical Sciences (CIOMS) in collaboration with the World Health Organization (WHO), Geneva 1993.

16. Barbanti $P$, Fabbrini $G$, Ricci $A$, Bruno $G$, Cerbo $R$, Bronzetti E, Amenta F, Luigi LG. Reduced density of dopamine D2-like receptors on peripheral blood lymphocytes in Alzheimer's disease. Mech Ageing Dev. 2000; 120: 65-75.

17. D'Andrea G, Granella $F$, Perini $F$, Farruggio $A$, Leone $M$, Bussone G. Platelet levels of dopamine are increased in migraine and cluster headache. Headache. 2006; 46: 585-591.

18. Agrawal A, Lynskey MT, Pergadia ML. Early cannabis use and DSM-IV nicotine dependence: A twin study. Addiction. 2008; 103: 1896-1904.

19. Jungermanv FS, Laranjeira R. Characteristics of cannabis users seeking treatment in Sao Paulo, Brazil. Rev Panam Salud Publica. 2008; 23: 384-393.

20. Cristiana MVM, Luigi $C$, Ranalli $P$, Giuseppe $M$. The sexual differentiation of Cannabis sativa $L$. A morphological and molecular study. Euphytica. 2004; 140: 95-106

21. Meloni $R$, Laurent $C$, Campion D. A rare allele of a microsatellite located in the tyrosine hydroxylase gene can be found exclusively in schizophrenic patients in two different ethnic populations. C R Acad. Sci. 1995; 318: 803-809.

Trop J Pharm Res, March 2020; 19(3): 480 
22. Jonsson EG, Geijer T, A. G. Failure to replicate an association between a rare allele of a tyrosine hydroxylase gene microsatellite and schizophrenia. Eur Arch Psychiatry Clin Neurosci. 1998; 248: 61-63.

23. Haycock JW. Species differences in the expression of multiple tyrosine hydroxylase protein isoforms. $\mathrm{J}$ Neurochem. 2002; 81: 947-953.

24. Kim DJ, et al. 5' UTR polymorphism of dopamine receptor D1 (DRD1) associated with severity and temperament of alcoholism. Biochem Biophys Res Commun. 2007; 357: 1135-1141.

25. Blum $K$, et al. Association of polymorphisms of dopamine D2 receptor (DRD2), and dopamine transporter (DAT1) genes with schizoid/avoidant behaviors (SAB). Mol Psychiatry. 1997; 2: 239-246.

26. Prasad $P$, Ambekar A, Vaswani M. Dopamine D2 receptor polymorphisms and susceptibility to alcohol dependence in Indian males: a preliminary study. BMC Med Genet. 2010; 11: 1-8.

27. Wiesbeck GA, Dürsteler-MacFarland KM, Wurst FM, Walter M, Petitjean S, Müller S, Wodarz N, J B. No association of dopamine receptor sensitivity in vivo with genetic predisposition for alcoholism and DRD2/DRD3 gene polymorphisms in alcohol dependence. Addict Biol. 2006; 11: 72-75.

28. Guindalini C, Laranjeira R, Collier D, Messas $G$, Vallada $H$, Breen G. Dopamine-beta hydroxylase polymorphism and cocaine addiction. Behav Brain Funct. 2008; 4: 1-4.

29. Kirov G, Jones I, McCandless F, Craddock N, Owen MJ. Family-based association studies of bipolar disorder with candidate genes involved in dopamine neurotransmission: DBH, DAT1, COMT, DRD2, DRD3 and DRD5. Mol Psychiatry. 1999; 4: 558-565. 